Dept. of Food Hygiene, Animals Health Research Institute,

Port-Said Laboratory.

\title{
INCIDENCE OF E. COLI IN MEAT AND EDIBLE OFFALS OF RABBIT CARCASSES AND THEIR PUBLIC HEALTH SIGNIFICANCES
}

(With 4 Tables)

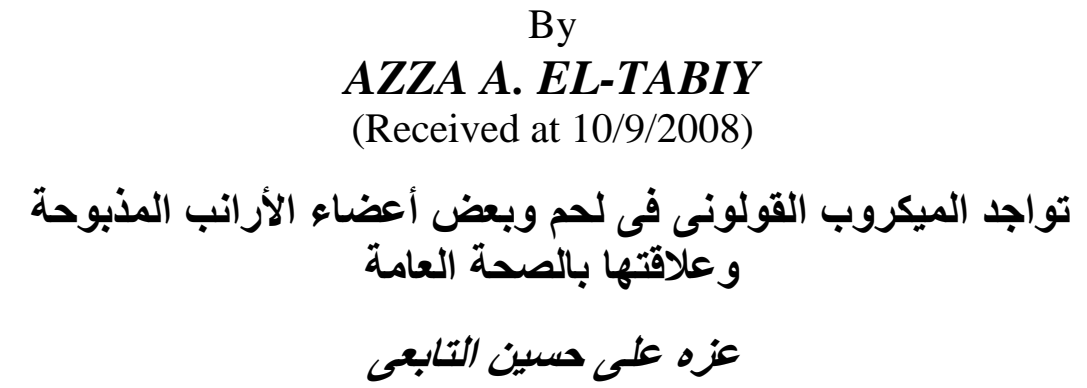

تم در اسة نو اجد الميكروب القولونى فى لحوم الأر انب وكذللك فى بعض الأعضاء الداخلية

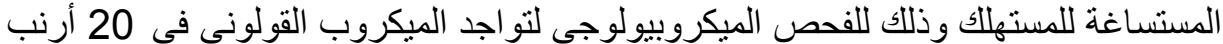

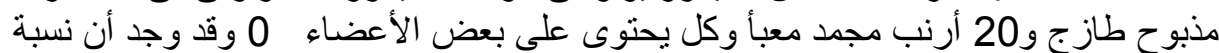

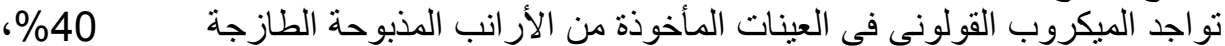

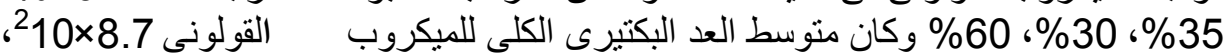
5

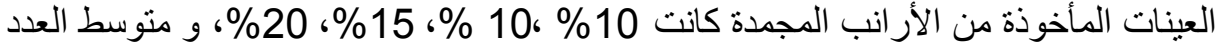

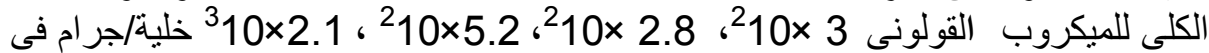

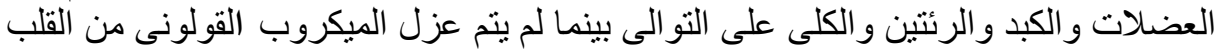

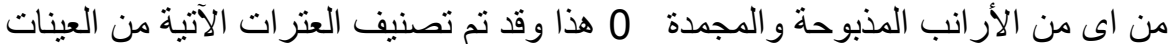

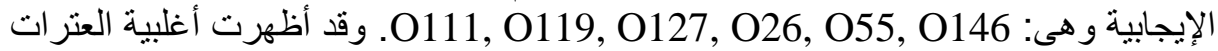

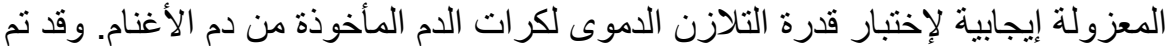

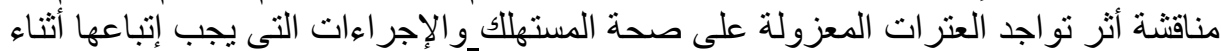
الذبح و إز الة الأحشاء الداخلية و التعبئة فى الأر انب وذلاتك لضَفمان سلامة المستهلك.

\section{SUMMARY}

A total number of 40 freshly slaughter and frozen packed rabbits (20 each), including its edible offals were collected from poultry butcher shops and different markets in Port-Said city. Samples from muscles and edible offals (liver, lungs, heart, and kidneys) were examined microbiologically for presence of Escherichia coli. The prevalence of $E$. coli in the examined unpacked fresh rabbit samples was $40,35,30$ and $60 \%$ with mean values of $8.7 \times 10^{2}, 5.0 \times 10^{2}, 3.9 \times 10^{2}$ and $4.2 \times 10^{3}$ 
CFU/gm, meanwhile the prevalence of E.coli in the examined packed frozen rabbit samples was $10,10,15$ and $20 \%$ with mean values of $3.0 \times 10^{2}, 2.8 \times 10^{2}, 5.2 \times 10^{2}$ and $2.1 \times 10^{3} \mathrm{CFU} / \mathrm{gm}$ in muscles, liver, lungs and kidneys respectively. The heart samples were found to be free from E. coli in both fresh and frozen samples. A total of 40 isolates recovered from fresh rabbit samples were identified to Serovars O55(20\%), O26(15\%), O127(12.5\%), O119(30\%), and O111(20\%), meanwhile E. coli belonging to Serovars O146(10\%), O55(23.3\%), O26(6.7), O127(13.3\%), O119(20\%) and O111(26.7\%) which constituted 30 isolates were recovered from frozen samples. The majority of E.coli serotypes recovered from the examined samples showed hemolytic activity. Public health significant of the isolated serogroups and sanitary control of rabbit meat and edible offals for consumer safety were discussed.

Key words: Rabbit carcasses, edible offals, E. coli.

\section{INTRODUCTION}

Rabbit meat has a highly palatable and digestible quality for consumers all over the world. Rabbit meat is tender and good source of protein, iron and phosphorus, low in total fat, saturated fat, cholesterol and sodium. Inspite of its nutritional and health advantages it has not been incriminated in outbreaks of food borne diseases (Lebas et al., 1997; Dalle Zotte, 2002).

E. coli infection of growing rabbits was the most serious problem among the enteric diseases. In industrial rabbit-fattening farms, enteritis caused by Escherichia coli is the main cause of morbidity and mortality in weaned rabbits. The native habitat of Escherichia coli is the enteric tract of man and animals, thus its presence in food generally indicates direct or indirect pollution of faecal origin. The pathogenic groups includes enterotoxigenic E. coli (ETEC), enteropathogenic E. coli (EPEC), enterohemorrhagic E. coli (EHEC), enteroinvasive E. coli (EIEC), enteroaggregative E. coli (EAEC), diffusely adherent E. coli (DAEC). of these, only the first 4 groups have been implicated in food or water borne illness (Levine, 1987; Nataro and Kaper. 1998).

Rabbit edible offals are an important part of rabbit carcasses. Offals are defined as those parts of the carcass which are disassembled on the dressing floor, and which form no part of the carcass when it is finally weighed and transferred to the chillers to undergo cooling. Offals are also often classified by the industry as green and red, depending on their origin. Although there is not complete agreement on the definition 
of the terms red and green offals, green offals will be defined as those derived from the digestive tract or those being in contact with the feed or grass, hence the term green. Red offals are those that do not come in contact with the contents of the digestive tract, so they are called red in contrast to the green (grass) offals. Using this classification system the tripe and casings would be called green offals, whereas the liver, kidneys, tongue, spleen, glands and heart would be classified as red offals. Offals, in particular liver have been described, as a route of transmission of organisms to human (Frazier and Westhoff, 1988). Literatures about the microbial quality of rabbit edible offals are rare. $E$. coli has an epidemiological interest and importance as some of which are pathogenic, so it is of great important to through the point on the prevalence and incidence of $E$.coli among rabbit carcasses and edible offals. Therefore, the present work was aimed to determine the incidence of E. coli among rabbit carcasses and offals. The public health significant and consumers safety were discussed.

\section{MATERIALS and METHODS}

\section{Collection of samples:}

A total number of 20 freshly slaughter rabbits, including its edible offals were collected from poultry butcher shops and placed separately into plastic sealed sterile bags. In addition, 20 frozen packed rabbits were collected from different markets in Port-Said city. All samples were transported to the laboratory in an ice box for investigation. Frozen samples were left to defrost in their original container at $4 \mathrm{C}^{\circ}$ for 6-12 hrs.

\section{Bacteriological examination:}

\section{I-Sample homogenization:}

10 grams of each muscles and offals sample (liver, lungs, heart, and kidneys) were blended with $90 \mathrm{ml}$ of freshly prepared butter field's phosphate buffer solution. Ten fold serial dilutions were prepared. The prepared dilutions were examined bacteriologically for detection of E. coli.

\section{II-Isolation and Enumeration of Escherichia coli:}

The technique recommended by APHA (1992) for isolation and identification of E. coli was carried out. One $\mathrm{ml}$ of each prepared dilution was inoculated separately onto Lauryl Sulphate Tryptose (LST) broth supplemented with inverted Durham's tubes, and was incubated at 
$37^{\circ} \mathrm{C}$ for $24-48 \mathrm{hrs}$. Tubes showing gas production were considered positive and recorded.

A loopful from each positive LST broth tube was inoculated onto E. coli broth tubes containing inverted Durham's tubes and incubated at $45.5 \pm 0.2{ }^{\circ} \mathrm{C}$ for $48 \mathrm{hrs}$. The tubes were examined at $24 \mathrm{hrs}$ for positive gas production and turbidity and the positive were recorded. Enumeration of E. coli was applied by using MPN Table based on proportion of EC. medium tubes in 3 consecutive dilutions according to FAO (1992).

A loopful of suspension from gassing EC. medium tubes was streaked onto Eosin Methylene Blue (EMB) agar plate and MacConkey Sorbitol agar (MACS) as double parallel by using spread plating. The plates were incubated at $37^{\circ} \mathrm{C}$ for $24 \mathrm{hrs}$.

\section{III-Biochemical identification:}

Biochemical tests were applied to metallic green colored, smooth sided colonies on EMB and to colorless or neutral /gray with smoky center and 1-2 mm diameter Sorbitol negative colonies on MACS according to Quinn et al. (2002).

\section{IV-Serological identification:}

The isolates were identified serologically by the slide agglutination test using diagnostic polyvalent and monovalent E. coli antisera (Escherichia coli antisera, Denka Seiken Co., Ltd, Tokyo, Japan), following the manufacturer's specification.

\section{V-Hemolysin production:}

E. coli isolates were inoculated onto blood agar plates containing sheep blood $(5 \%)$ and incubated at $37^{\circ} \mathrm{C}$ for $24 \mathrm{hrs}$. The plates were examined for the presence of hemolysis (Beutin et al., 1989).

\section{RESULTS}

Table 1: Prevalence of $E$ coli in the examined rabbit carcasses and edible offals: $(n=20$ each $)$

\begin{tabular}{|c|c|c|c|c|c|c|c|c|c|c|c|c|}
\hline \multirow{3}{*}{$\begin{array}{c}\text { Examined rabbit } \\
\text { Samples }\end{array}$} & \multirow{2}{*}{\multicolumn{2}{|c|}{$\begin{array}{l}\text { Muscles } \\
\qquad(n=20)\end{array}$}} & \multicolumn{8}{|c|}{ Edible offals } & \multirow{2}{*}{\multicolumn{2}{|c|}{ Total }} \\
\hline & & & \multicolumn{2}{|c|}{$\begin{array}{l}\text { Liver } \\
(\mathrm{n}=20)\end{array}$} & \multicolumn{2}{|c|}{$\begin{array}{l}\text { Lungs } \\
(\mathrm{n}=20)\end{array}$} & \multicolumn{2}{|c|}{$\begin{array}{l}\text { Heart } \\
(n=20)\end{array}$} & \multicolumn{2}{|c|}{$\begin{array}{c}\text { Kidneys } \\
(n=20)\end{array}$} & & \\
\hline & $+v e$ & $\%$ & $+\mathrm{ve}$ & $\%$ & $+\mathrm{ve}$ & $\%$ & $+v e$ & $\%$ & $+v e$ & $\%$ & + ve & $\%$ \\
\hline $\begin{array}{c}\text { Unpacked fresh } \\
(20)\end{array}$ & 8 & 40 & 7 & 35 & 6 & 30 & 0 & 0 & 12 & 60 & 33 & 33 \\
\hline $\begin{array}{l}\text { Packed frozen } \\
\text { (20) }\end{array}$ & 2 & 10 & 2 & 10 & 3 & 15 & 0 & 0 & 4 & 20 & 11 & 11 \\
\hline
\end{tabular}

NB: The percentage was calculated in relative to the total number of each sample (20). 
Table 2: Statistical analytical results of $E$ coli count (MPN/gm.) recovered from fresh and frozen rabbit carcasses and edible offals.

\begin{tabular}{|c|c|c|c|c|c|c|c|c|c|}
\hline & \multicolumn{4}{|c|}{ Unpacked fresh samples } & \multicolumn{4}{|c|}{ Packed frozen samples } \\
\hline & & Muscles & Liver & Lungs & Kidneys & Muscles & Liver & Lungs & Kidneys \\
\hline \multicolumn{2}{|c|}{$\begin{array}{c}\text { Total } \\
\text { samples }\end{array}$} & 20 & 20 & 20 & 20 & 20 & 20 & 20 & 20 \\
\hline \multicolumn{2}{|c|}{$\begin{array}{c}\text { ND } \\
\text { Samples }\end{array}$} & 12 & 13 & 14 & 8 & 18 & 18 & 17 & 16 \\
\hline \multicolumn{2}{|c|}{$\begin{array}{c}+\mathrm{ve} \\
\text { Samples }\end{array}$} & 8 & 7 & 6 & 12 & 2 & 2 & 3 & 4 \\
\hline \multirow{5}{*}{ 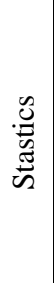 } & Min. & $2.5 \times 10^{2}$ & $2.0 \times 10^{2}$ & $2.0 \times 10^{2}$ & $4.0 \times 10^{2}$ & $2.0 \times 10^{2}$ & $2.5 \times 10^{2}$ & $2.0 \times 10^{2}$ & $2.0 \times 10^{2}$ \\
\hline & Max. & $4.3 \times 10^{3}$ & $2.0 \times 10^{3}$ & $1.1 \times 10^{3}$ & $4.3 \times 10^{4}$ & $4.0 \times 10^{2}$ & $3.0 \times 10^{2}$ & $1.1 \times 10^{3}$ & $7.5 \times 10^{3}$ \\
\hline & Mean & $8.7 \times 10^{2}$ & $5.0 \times 10^{2}$ & $3.9 \times 10^{2}$ & $4.2 \times 10^{3}$ & $3.0 \times 10^{2}$ & $2.8 \times 10^{2}$ & $5.2 \times 10^{2}$ & $2.1 \times 10^{3}$ \\
\hline & S.D & $1.3 \times 10^{3}$ & $6.6 \times 10^{2}$ & $3.5 \times 10^{2}$ & $1.2 \times 10^{4}$ & $1.4 \times 10^{2}$ & $3.5 \times 10^{1}$ & $5.1 \times 10^{2}$ & $3.6 \times 10^{3}$ \\
\hline & S.E \pm & $4.9 \times 10^{2}$ & $2.5 \times 10^{2}$ & $1.4 \times 10^{2}$ & $3.5 \times 10^{3}$ & $1.0 \times 10^{2}$ & $2.5 \times 10^{1}$ & $2.9 \times 10^{2}$ & $1.8 \times 10^{3}$ \\
\hline
\end{tabular}

Min. $=$ Minimum. $\quad$ Max. $=$ Maximum. $\quad$ SE $\pm=$ Standard Error

$\mathrm{SD}=$ Standard Deviation $\quad \mathrm{ND}=$ not detected

Table 3: Serovars of $E$ coli isolates recovered from the examined fresh unpacked and frozen packed rabbit carcasses

\begin{tabular}{|c|c|c|c|c|c|c|c|c|c|c|c|c|c|}
\hline \multirow{2}{*}{$\begin{array}{c}\text { Serovars } \\
\text { Source }\end{array}$} & \multirow{2}{*}{$\begin{array}{c}\text { Total no. } \\
\text { of isolates }\end{array}$} & \multicolumn{2}{|c|}{ O 146} & \multicolumn{2}{|c|}{ O 55} & \multicolumn{2}{|c|}{ O 26} & \multicolumn{2}{|c|}{ O 127} & \multicolumn{2}{|c|}{ O 119} & \multicolumn{2}{|c|}{ O111 } \\
\hline & & No. & $\%$ & No. & $\%$ & No. & $\%$ & No. & $\%$ & No. & $\%$ & No. & $\%$ \\
\hline $\begin{array}{c}\text { Fresh } \\
\text { unpacked } \\
\text { samples }\end{array}$ & 40 & 0 & 0 & 8 & 20 & 6 & 15 & 5 & 12.5 & 12 & 30 & 9 & 22.5 \\
\hline $\begin{array}{c}\text { Frozen } \\
\text { packed } \\
\text { samples }\end{array}$ & 30 & 3 & 10 & 7 & 23.3 & 2 & 6.7 & 4 & 13.3 & 6 & 20 & 8 & 26.7 \\
\hline Total & 70 & 3 & 4.3 & 15 & 21.4 & 8 & 11.4 & 9 & 12.9 & 18 & 25.7 & 17 & 24.3 \\
\hline
\end{tabular}

Table 4: Hemolytic activity of the isolated serovars

\begin{tabular}{|c|c|c|c|}
\hline \multirow{2}{*}{ E. coli Serovars } & No. of isolates & \multicolumn{2}{|c|}{ Hemolytic activity } \\
\cline { 3 - 4 } & & No. & $\%$ \\
\hline O146 & 3 & 2 & 66.7 \\
\hline O55 & 15 & 12 & 80 \\
\hline O26 & 8 & 4 & 50 \\
\hline O127 & 9 & 9 & 100 \\
\hline O 119 & 18 & 15 & 83.3 \\
\hline O111 & 17 & 17 & 100 \\
\hline Total & 70 & 59 & 84.3 \\
\hline
\end{tabular}




\section{DISCUSSION}

The present results achieved in Tables $1 \& 2$ revealed that the prevalence of $E$. coli in the examined unpacked fresh rabbit samples was $40,35,30$ and $60 \%$ with mean values of $8.7 \times 10^{2}, 5.0 \times 10^{2}, 3.9 \times 10^{2}$ and $4.2 \times 10^{3} \mathrm{CFU} / \mathrm{gm}$, meanwhile the prevalence of $E$. coli in the examined packed frozen rabbit samples was $10,10,15$ and $20 \%$ with mean values of $3.0 \times 10^{2}, 2.8 \times 10^{2}, 5.2 \times 10^{2}$ and $2.1 \times 10^{3} \mathrm{CFU} / \mathrm{gm}$ in muscles, livers, lungs and kidneys respectively. The hearts were free from $E$. coli in both fresh and frozen samples. Ghoniem et al. (1971) isolated E. coli from slaughtered rabbits at higher rate from the livers $(60 \%)$, the lower rate was in the lungs (7.15\%). However Samaha et al. (1993) reported that the incidence of $E$.coli in fresh livers, and hearts was $4.76 \%$ and $23.8 \%$ respectively. Meanwhile $E$. coli was isolated a lower rate represented $13.6 \%$ and $4.5 \%$ from livers and hearts respectively from freshly slaughtered apparently healthy rabbits (El-Tabiy, 1998). The present results declared that higher incidence of $E$. coli was recorded in the examined unpacked fresh rabbit samples. Moreover, the achieved results proved that kidneys had a higher incidence of E. coli and it was higher in fresh samples. Nearly similar findings were recorded previously by Khalaf-Alla (1993) and Abu-Taleb (1995).

Freezing significantly influenced the rate and extent of microorganisms growth. (Katarzyna and Hanna, 2003). Freezing is an easiest, ancient and most convenient method of food preservation. Freezing stop the bacterial action by halts the activities for spoilage microorganisms in and on food (Archer, 2004). Although food, is not sterilized by freezing but the bacterial count and growth is reduced during the cold storage (Moore and Madden, 2001).

E. coli counts considered as reflection of environmental contamination during slaughter processing and /or product handling, and its count is an index of sanitary quality of the examined rabbit samples. High number can easily give rise to public health hazards (Mercuri and Cox 1976; Kanpelancher 1981).

E. coli is a member of coliform group which are referred as general indicator organisms to measure the potential presence of enteric pathogens in food, also measure the fecal contamination of the food products. Bobbitt (2003) mentioned that the total coliform count of fresh rabbit carcasses was $6.2 \times 10^{4} \mathrm{CFU} / \mathrm{gm}$. In this respect Rodriguez-Calleja et al. (2004) reported that the mean coliform count was $1.55 \pm 0.72 \mathrm{log}$ $\mathrm{CFU} / \mathrm{g}$ for rabbit carcasses dressed at a small abattoir and was 2.02 \pm 
$0.79 \log \mathrm{CFU} / \mathrm{g}$ for rabbit carcasses stored in Spain supermarkets, he found that the number of positive samples of E.coli was 4 from 12 samples in rabbit carcasses slaughtered at small abattoir. Also Maghraby (2005) revealed that the mean values of coliform were $1.7 \times 10^{3}$ and $2.5 \times 10^{2}$ in fresh and frozen rabbit carcasses respectively.

The results of biochemical and serological identification of E.coli isolates were recorded in Table 3. E. coli isolates recovered from fresh samples were belonging to Serovars O55(20\%), O26(15\%), O127(12.5\%), O119(30\%) and O111(20\%), meanwhile O146(10\%), O55(23.3\%), O26(6.7), O127(13.3\%), O119(20\%) and O111(26.7\%) serovars could be identified from frozen samples (Table 3). Nearly similar serotype isolates were recorded by Gross (1991) and Brook et al. (1994). Ali (1995) recovered 34 isolates of E. coli $57.6 \%$ from the examined suckling rabbits and were serotyped as 4 isolates (O55), 6 isolates (O119), 14 isolates (O128) and 10 isolates (O126). Most of the isolated $E$. coli serotypes are usually associated with many cases of food borne outbreaks. In this concern, Mossel et al. (1995) listed E. coli as one of the causes of febrile types of gastroenteritis transmitted by foods. They reported that the $\mathrm{O} 111$ and $\mathrm{O} 127$ as members of the group containing major virulence factors and they considered some of the $\mathrm{O} 111$ is verocytotoxine producers and some as enterohaemorrhagic types, the $\mathrm{O} 127$ they tabulated as devoid of toxin production but give rise to attachment effacement lesions in the intestinal mucosa and so profuse diarrhea by adhering to the intestinal epithelium and distorting the microvilli and by causing attaching and effacing lesions. E. coli Serovars O111 and O119 were enteropathogenic E. coli class I which are responsible for many cases of infantile diarrhea (Jay, 1992). Hussein and Omaye (2003) found that the serogroups belonging to O26, O113, O111, O119 and O166 have caused approximately $30 \%$ of the hemolytic uremic syndrome (HUS) in US.

The majority of $E$. coli serotypes isolated from the examined samples showed hemolytic activity (Table 4). In this respect, Adesiyun et al. (1997) reported that from 94 E. coli isolates tested for haemolysis $13.8 \%$ were hemolytic. Meanwhile, Soliman and El-Tabiy (2006) reported that from 60 E. coli isolates tested for hemolytic activity $81.7 \%$ were positive. Haemolysin productions have a potential role in virulence of hemolytic E. coli. Therefore, the contamination of products with E. coli serotypes may results in problems for consumers. Moreover, the genes involved in enterohaemolysin production were carried on the EHEC plasmid (Scotland et al., 1990). Several protein toxins associated 
with E.coli pathogenesis have been identified, including haemolysins. The production of haemolysins by $E$. coli is associated with extraintestinal infections in man, and thus haemolysins are considered to play an important role in pathogenesis. (Lai et al., 2000).

Bacteria belonging to the family Enterobacteriaceae in rabbit meats are undesirable; their presence may be attributed to contamination of surface of carcasses from exterior of the animals and intestinal contents during evisceration and dressing. Rabbit meat and edible offals need control to safe guard of consumer against food poisoning, outbreaks and to save rabbit carcasses from being spoiled on the market. The slaughterhouse and its regulations, represents a key control point of the livestock production chain. In this context, the noteworthiness of hygienic and sanitary control of rabbit meat slaughtering should be emphasized since the growing interest of consumers in this meat. The rabbit carcasses must be packaged with un separate head while the edible offals (liver, kidneys, lung and heart) should be clean, healthy, and free from gall bladder and packaged separately from the carcasses (E.O.S.Q.C.1996). The use of aseptic packaging of the finished product should be encouraged to avoid post processing environmental contamination as well as keeping the meat frozen during transportation and sale.

\section{REFERENCES}

Abu-Taleb, S.M.S. (1995): Sanitary evaluation of slaughtered rabbits. M.V.Sc. Zagazig University. Meat hygiene, Food control department.

Adesiyun, A.A.; Webb, L.A.; Romaine, H. and Kaminjolo, J.S. (1997):

Prevalence and characteristics of strains of Escherichia coli isolated from milk and feces of cows on dairy farms in Trinidad. J. Food Protect, 60: 1174-1181.

Ali, A.M.A. (1995): Mortalities in suckling rabbits with special reference to microbial agents. (Poultry and rabbit diseases) M.V.Sc Suis Canal Unv.

APHA (American Public Health Association) (1992): Compendium of Methods for the Microbiological Examination of Foods $3^{\text {rd }}$ ed., Vanderzant, C. and Splittstoesser, F. (Eds.) APHA, Washington, D.C.

Archer, D. (2004): Freezing: an underutilized food safety technology. International Journal of Food Microbiology. 90: 127-138. 
Bobbitt, J. (2003): Buffalo, camel, crocodile, emu, Kangaroo, ostrich and rabbit meat. New Value Added Products. Rural Industries research and Development Corporation Publ. No. 03-036.

Brook, M.G.; Smith, H.R. and Bannister, B.A. (1994): Prospective study of verocytotoxine producing, enteroaggregative and diffusely adherent Escherichia coli in different diarrheal states. Epidemiol. Infect. 112: 63-67.

Beutin, L.; Montenegro, M.A.; Orskov, I.; Orskov, F.; Prada, J.; Zimmermann, S. and Stephen, R. (1989): Close association of verotoxin (Shiga like toxin) production with enterohaemolysin production in strains of E. coli. J. Clin. Microbiol., 27 (11): 2559- 2564.

Dalle Zotte, A. (2002): Perception of rabbit meat quality and major factors including the rabbit carcasses and meat quality. Livest. Prod. Sci. 75: 11-15.

El-Tabiy, A.A.H. (1998): Properties of E. coli strains isolated from septicaemic rabbits and chickens. Ph.D. (Bacteriology, Immunology and Mycology). Sues Canal University.

E.O.S.Q.C., (1996): Egyptian Organization for Standardization and Quality Control. Frozen Poultry and Rabbits. Es: 1090-1996.

FAO "Food and Agriculture Organization" (1992): Escherichia coli and other coliforms. Manual of Food Quality Control. 4Rev. 1Microbiological Analysis. Food and Agriculture Organization of the united Nation, Rome, Italy, Chap. 3 pp 13-26.

Frazier, W.C. and Westhoff, D.C. (1988): Contamination, preservation, and spoilage of meats and meats products. Food Microbiology $4^{\text {th }}$ Ed. (McGraw-Hill, New York), 223, pp. 218-242.

Ghoniem, N.; Zein El-Abdin, Y. and Abdel-Hady, H. (1971): Studies on pathogenic microorganisms in domestic rabbits in U.A.R.J. Egypt. Vet. Med. Assoc., 31: 227-234.

Gross, R.J. (1991): The pathogenesis of Escherichia coli diarrhea. Rev. Med. Microbiol. 2: 37-23.

Hussein, H.S. and Omaye, S.T. (2003): Introduction of food safety concerns of verotoxin producing Escherichia coli. Exp. Biol. Med. (Maywood)., 228 (4): 331-332.

Jay, J.M. (1992): Modern Food Microbiology $4^{\text {th }}$ Ed. Van Nostrand Reinhold. New York.

Kanpelancher, K.H. (1981): Lab. For food microbiol and hygiene. Agric. Univ., wagninen, Netherland. Zentablatt for, Bacteriologic. IB 172 (4/5): 390. 
Katarzyna, D. and Hanna, R. (2003): Microbiological quality of Polish edible offalss processed meat products during storage: influence on n-nitrosamines content. Bull. Vet. Inst. Pulawy 47, 217-223.

Khalaf-Alla, F.A. (1993): Microbiological status of rabbit carcasses. Z. Lebensm Unters. Forsch. A.196: 233.

Lai, X.H.; Johansson, A.I.; Wai, S.N.; Oscarsson, J.; Kalfas, S.; Sundqvist, K.G.; Mizunoe, Y.; Sjostedt, A. \& Uhlin, B.E. (2000): Cytocidal and apoptopic effects of the ClyA protein from Escherichia coli on primary and cultured monocytes and macrophages. Infect. Immunol. 68, 4363-4367.

Lebas, F.; Coudert, P.; De Rochanbeau, H. and Thebault, R.G. (1997): The rabbit husbandry, health and production. Animal production. Animal production and health Series No. Food and Agriculture Organization. Rome.

Levine, M.M. (1987): Escherichia coli that cause diarrhea enterotoxigenic, enteroinvasive, enterohemorrhagic, and enteroadherent. J. Infect. Dis., 155: 377-389.

Maghraby, O.M.E. (2005): Evaluation of rabbit carcasses. Egypt. Vet, med. Assoc. 65, No.3: 273- 281.

Mercuri, A.J. and Cox, N.A. (1976): Coliforms and Enterobacteriaceae isolated from selected food. J. Food Protect., 9: 712-714

Moore, J. and Madden, R. (2001): "Survival of Campylobacter coli in porcine liver. Food Microbiol. 18:1-10.

Mossel, D.A.A.; Corry, J.L.; Struijk, C.B. and Baird, R.M. (1995): Essentials of the Microbiology of Food. (Ed.). A Text book for advanced studies. John Willey \& Sons. Chichester. New York. Brisbane.

Nataro, J.P. and Kaper, J.B. (1998): Diarrheagenic Escherichia coli. Clin. Microbiol. Rev., 11: 132-201.

Rodriguez-Calleja, J.M.; Santos, J.A.; Otero, A. and Garcia-Lopez, M.L. (2004): Microbiological quality of rabbit meat. J. Food Protect. 67: 966-970.

Samaha, I.A.; Mousa, M.M. and El-Gohary, A.H. (1993): Occurrence and public health importance of enterobacteriaceae in giblets at consumer level. Alex. J. Vet. Sci.9 (4):79.

Scotland, S.M.; Willshaw, G.A.; Smith, H.R. and Rowe, B. (1990): Properties of strains of Escherichia coli O26: $\mathrm{H} 11$ in relation to their enteropathogenic or enterohemorrhagic classification. J. Infect. Dis., 162 (5): 1069-1074. 
Soliman, A. and El-Tabiy, A. (2006): A study on the occurrence of Escherichia coli in some beef products with special reference to Escherichia coli O157:H7. Assiut Vet. Med. J. 110. (52): 75-87.

Quinn, P.J.; Markey, B.K.; Carter, M.E.; Donelly, W.J.C. and Leonard, F.C. (2002): Veterinary Microbiology and Microbial Diseases. $1^{\text {st }}$ Iowa State University Press Blackwell Science. 